\title{
FACTORS INFLUENCING FARM CRIME IN KENYA: OPINIONS AND EXPERIENCES OF FARMERS ${ }^{1}$
}

Emmanuel K. Bunei

Land Reclamation Officer

Ministry of Water and Irrigation,

P. O. Box 49720

Nairobi, Kenya

Joseph K. Rono

Lecturer, Department of Sociology and Psychology,

Moi University

P.O. Box 3900

Eldoret, Kenya.

Samuel R. Chessa

Lecturer, Department of Sociology and Psychology,

Moi University

P.O. Box 3900

Eldoret, Kenya.

Contact Author - E. K. Bunei; ebunei2001@ yahoo.com, +254 724917456

\begin{abstract}
Although agriculture is the backbone of Kenya's economy, the industry is faced with rapid social, cultural, economic, and technological changes that have significantly increased crime levels in rural areas. In particular, communal, social, and individual controls are diminishing, and the result is an increase of criminal activities against agricultural operations. The aim of the study was to assess factors associated with levels of agricultural theft and vandalism in Kenya, based on the perceptions of farmers themselves. The research was carried out in the Soy division of Uasin Gishu County. A multistage sampling approach, which incorporates purposive, random, and systematic techniques, was used to select respondents within the case study locations. A semi-structured questionnaire was administered to a representative sample of 200 farmers. Key informant interviews and informal discussions were conducted with local administration officers, namely, village elders, sub chiefs and chiefs, to supplement information derived from the survey. The study used routine activity theory to explain how perceived changes in communities where the farmers lived have created opportunities for the commission of crime. Based on the findings, the study recommends programs which create employment opportunities for both youth and disadvantaged persons in rural Kenya.

Keywords: Farm Crime; Routine Activity Theory, Agriculture Ecological Factors, Socioeconomic Factors
\end{abstract}




\section{Factors Influencing Farm Crime in Kenya: Opinions and Experiences of Farmers: \\ Bunei, Rono \& Chessa}

\section{Introduction}

Agriculture is vital to Kenya's economy and contributes around 25 percent of the country's Gross Domestic Product (GDP) (Republic of Kenya, 2006; 2008). It is estimated that 70 percent of the total labour force derives its livelihood from agriculturally-related industries, with 18 percent engaging in formal employment within this sector, and another 3.7 million small and micro-enterprise sector jobs (Owuor, Job, Collin, \& Argwings, 2010; Republic of Kenya, 2006, p. 1; 2008, p. 158;). Further, it accounts for 65 percent of Kenya's total exports, and is 45 percent of government revenues (Republic of Kenya, 2006).

About 80 percent of Kenya's population lives in rural areas and most rely on small scale agriculture for their subsistence (Republic of Kenya, 2008). The average size of a land plot for small scale farmers is only five acres, while larger scale farms average about 100 acres, although a few operations may be as large as 2,000 acres.

Maize, wheat, coffee, tea, and pyrethrum are some of the more important crops grown by farmers in the study region (Republic of Kenya, 2008). Livestock rearing is also prevalent with almost every farmer keeping some cattle, sheep, and goats. A few farm families keep their livestock under a strict zero-grazing system (Republic of Kenya, 2008). Milk production has been increasing over the years, partly as a result of diminishing returns from crop production due to land fragmentation, low soil fertility, and unpredictable prices for produce (Owuor et al., 2010; Republic of Kenya, 2008). Agriculture-related industries include food processing and handling, flour milling, and the transportation of agricultural produce and inputs.

Kenya's agriculture is mainly rain-fed and is almost entirely dependent on the availability of rainfall in most parts of the country. Only 15 percent of Kenya's total land area has sufficient fertility to be farmed. Over 80 percent of Kenya's land surface is considered arid and semi arid with less than $400 \mathrm{~mm}$ of rainfall in a year, which makes farming unattractive in many regions of the country (Republic of Kenya, 2006 \& 2008).

Agriculture is a major activity in 10 of Kenya's counties, with production centered in the high agricultural potential counties in the greater Rift Valley Provinces, such as Uasin Gishu, Tran Nzoia, and Narok Counties. These alone account for more than 75 percent of Kenya's food production (Coast Weekly, 2012; Republic of Kenya, 2006; 2008). The counties are rightly referred to as part of the "grain basket" of the country (Daily Nation, 2011a, p. 26; Owuor et al, 2010, p 4). They produce wheat and maize in large quantities and livestock rearing is also prevalent. Gradually, vegetable and fruit production is emerging both here and in most other parts of the country. The commidities include French beans, passion fruit, peas, and tomatoes. Also grown are cabbages, kales, and avocados (Owuor et al, 2010, p. 4). 
Agricultural enterprises in Kenya, like other sectors of the economy, have witnessed changes which have brought technological, economical, and social-cultural revolutions in the operation of agricultural enterprises (Daily Nation, 2011a, p 26; Owuor et al, 2010, p 4). Changes such as the increased cost of farm produce and farm inputs, the cost of living, unemployment, urbanization, increased competition in the farming sector, mechanization, diminished informal control, and improvement in roads and other transportation systems have create many more opportunities for criminal activities than in the past (Barclay \& Donnemeyer, 2011; Marshall \& Johnson, 2005).

As a result of numerous transformations within Kenya, crime in rural areas has become a bigger problem today, with isolated rural locations becoming prime targets for theft, especially agricultural operations. Criminals are able to steal with little chance of being seen (Coast Weekly, 2012; Syverson, 2009). Farm crime is now a significant area of organized criminality and of concern to rural communities. As well, agricultural crime is a problem of major concern across the world (Barclay, 2001; Jones, 2008; Mears et al, 2007a; Spore Magazine, 2009), with estimated economic loss being as high as $\$ 5$ billion on an annual basis (Swanson et al, 2000, p. 628). Yet, there is a general assumption that crimes against agricultural operations are of little import and not of interest to the police or to criminology scholars (Swanson, Chamelin \& Territo, 2000, p. 628).

Worse still, these crimes are not reported as much as residential crime and crime to other types of businesses (Barclay et al, 2001; Mears et al, 2007a), and remains unknown by criminal justice institutions in Kenya and Africa in general. Hence, there has been little attention towards the study of patterns and causes of agricultural crimes on the African continent (Republic of Kenya, 2008).

The main aim of this paper is to explore causes of farm crime in Kenya from the point of view of farmers. Research on farm crime in Kenya and Africa in general remains nonexistent, with most information being derived from media reports (Coast Weekly, 2012; Daily Nation, 2011). Reliance on the opinions of crime victims alone should be treated with caution since their experiences may lead to either underestimation or exaggeration of factual information due to fear, the anticipation of compensation, and other factors (Andrig \& Barasa, 2011, p. 95). However, victimization studies provide a useful way to understand the patterns of crime and how farmers as the potential victims perceive their situation.

\section{Review on Literature}

\section{The Nature of Rural Communities}

Rural areas throughout the world have common characteristics. Generally, their populations are geographically or spatially dispersed, and many rural localities are socially isolated when compared to city environments (Feyen, 1989). Agriculture is often the 


\section{Factors Influencing Farm Crime in Kenya: Opinions and Experiences of Farmers: \\ Bunei, Rono \& Chessa}

dominant and sometimes the exclusive economic activity in rural areas. Rural communities are characterised by a more homogeneous population and a greater level of social cohesion, connection, intimacy, and shared values based on informal social relationships (Bouffard \& Muftíc, 2006; Marshall \& Johnson, 2005). According to Barclay and Donnermeyer (2002), the media often perceives rural areas as places characterized by friendliness and togetherness, and as areas with relatively little crime, representing (perhaps falsely), the concept of gemeinschaft that is so famously associated with Tonnies (1963). Interactions among people living in rural areas tends to be more personal, with a greater number of community members having intimate or personal relationships with each other (Bouffard \& Muftíc, 2006).

Rural peoples have distinctive sets of attitudes, beliefs, values, knowledge systems, and behaviours that help to strengthen informal controls, and prevent some kinds of deviant behaviour and crime, even though these same forms of control may enhance other kinds of crime (Donnermeyer, 2006). Some rural areas have stereotypes about the world and causality which are deeply rooted in culture, are difficult to change, and which promote intolerance of new ideas and people (Marshall \& Shane, 2005). In the Australian studies, many victims were placed under pressure to conform, keep the peace, and to not accuse someone in the community of theft (Barclay et al, 2001, p. 155). It is especially important for the victim to remain silent and not to report a neighbour as a suspect to avoid ostracism from the community (Barclay et al., 2001). Great importance is placed on the strength of a united community, most especially during hard times like floods, bushfires, and economic hardship. Thus, victims would rather trade off their losses of produce and animals, or sell their properties, than to be subjected to exclusion from their community. This defeats efforts to improve community-police relationships and can distort levels and data of farm and other crimes in rural areas (Barclay, 2001). Rural areas next to urban centres generally experience more crimes than remote regions, leading to the conclusion that perpetrators of crime in rural areas and on farms take advantage of transportation systems and distances to re-sell purloined property (Swanson et al, 2000, p. 628).

\section{Farm Crime}

Several studies have been conducted on farm crime in different parts of the world, especially in Australia, the United Kingdom, and the United States. These studies provide some preliminary evidence about the current patterns, causes, and consequences of farm crime. These studies consistently found that most farm crime is property-related, including the theft of livestock, spare parts, tractors, and other machinery, fuel, tools, agrichemicals, and farm produce (such as maize, wheat, vegatables, and fruits), and the destruction of property (i.e., vandalism) (Anderson and McCall, 2005; Barclay, 2001; Donnermeyer \& Barclay, 2005; Jones, 2008; Mears et al, 2007a).

Barclay (2001) conducted a review of literature on agricultural crime and found that crime against farms is widespread and costly to farmers. As well, previous studies have 
shown that: (1) large farms tend to experience more victimization than smaller ones (McCall, 2003, p. 6; Mears et al, 2007a); (2) farmers use less security measures and are reluctant to report crimes (Jones, 2008, p. 12); and (3) even though farms are isolated, farm property can be easily accessible from public roads, and have many portable commodities and items which are easy to steal (Barclay et al, 2001). Research also suggests that employee theft can be a problem (Donnermeyer \& Barclay, 2002; Swanson et al, 2000, p. 628), especially on farm operations that rely upon seasonal and low-paid workers (Anderson \& McCall, 2005, p. 35).

A literature search from developed nations shows that farm crime is linked to the specific nature of physical, social, geographical, and cultural environments of farming communities and areas (Anderson \& McCall, 2005; Barclay, 2001; Barclay et al 2001; Jones, 2008; Mears et al, 2007a). According to Barclay et al (2001), unemployment and drug abuse are the most common social problems linked to farm crime. A study conducted in Australia by Anderson and McCall (2005) showed that isolated farmlands, larger farms with higher incomes, and proximity to urban centres were the greatest predictors of being a victim of various types of farm crime. Although isolated farmlands and proximity to urban centres seem to be contradictory correlates of agricultural crime, they are not. The isolation refers to the distance from one farm to another, which affects guardianship. Hence, there is a large flow of non-local people (especially by road) in farm areas near towns. Plus, a farm family's house may be too far from storage buildings, supplies, livestock and other valuable property to be seen, and farm neighbours can still be far enough away from each other so as not to notice intruders and thieves.

Similar studies conducted by Mears et al (2007a; 2007b) in the U.S. found that farm properties which are highly attractive, portable, and have high value, such as fruits and nuts, were more likely to experience theft. Further, proximity in terms of target and offender has been shown by several studies to be linked to high rates of farm crime victimisation. Studies by Mears et al (2007a) and Barclay (2001) found that farm theft was related to the number employees on the farm, with some farm workers being responsible for crime directly, or by passing information to criminals for a fee. Further, Swanson et al (2000) argued that farmers themselves constitute a source of support for farm theft and may readily purchase stolen commodities at a bargain price. The overriding conclusion is that property crime on farms is highly situational, with certain factors being strongly associated with certain types of farm crimes (Barclay et al, 2001).

Even though most empirical studies on agricultural crime have been conducted in Australia, the United Kingdom and the United States (Anderson \& McCall, 2005; Barclay, 2001; Barclay et al, 2001; Jones, 2008; Mears et al, 2007a), factors that explain the various types of farm crime in third world countries, such as Kenya, have not been well understood. Indeed, farm crime presents major problems to farm economies in these countries. Thus, such 


\section{Factors Influencing Farm Crime in Kenya: Opinions and Experiences of Farmers: \\ Bunei, Rono \& Chessa}

crimes must be given the due attention they deserve if agricultural crime is to be effectively reduced and managed in a growing and increasingly globablised economy.

\section{Routine Activity Theory}

Routine activity theory is one of the main theories of environmental criminology. It argues that criminal offences are directly related to patterns of daily social interaction of both victims and offenders, which define in part the situation or context under which crime takes place. According to Cohen and Felson (1979), in order to occur, crime requires a motivated offender, in the absence of a capable guardian, and the presence of a suitable target. If these three elements converge in time and space, then criminal opportunity is said to be present.

A motivated offender in this theory is anyone who has the tendency or inclination to commit the crime. Target refers to the object or person against which the crime occurs. Capable guardianship includes anyone or any object (i.e., forms of physical security) which can limit the chances of an offender committing a crime (Cohen \& Felson, 1979, p 590). According to routine activity theory, motivated offenders usually make a decision based on the characteristics of the target. A target can be person, place, or property. The choice of target depends on its value, accessibility, visibility, concealability, removability, and disposability. An increase in any of these qualities may lead to an increase in the likelihood of victimization (Felson 1979). Bursik and Grasmick (1993) discussed the work of Cohen and Felson (1979) by referring to guardianship as both a human (human presence or physical guardianship) and a non-human (e.g. locks, alarms) phenomenon. Guardianship is the availability of others who may prevent crimes by their mere presence or by offering assistance to ward off an attack. Capable guardianship can include neighbours, friends, relatives, passersby, plus physical measures like locks, alarms, and remote cameras; all of these can act as substantial obstacles to offenders (Clarke \& Felson, 1993).

The nature of rural communities, coupled with transformations in their social, cultural, and economic makeup, tends to increase the number of offenders and reduce guardianship, exposing farm property to greater risk. Mears et al (2007b) note that farms are vulnerable to crime because they tend to be more isolated, occupy large tracts of land, are near people who potentially would steal from them, including neighbours and employees, and are rarely guarded. They further argue that there is a traditional reluctance by farmers to seek help from law enforcement, which may serve to increase the opportunities for farm crime victimization.

Routine activity theory stresses the importance of the exposure of property as a key ingredient in assessing vulnerability. In a farm setting, however, exposure is seemingly absent because farms are isolated. However, guardianship on a large farm where a great deal of the property is far from where the owner lives tends to be minimal and is not effective in reducing the vulnerability of property (Mears et al, 2007b). Barclay and Donnermeyer (2002) observed that many agricultural crimes occur at specific places on agricultural operations and 
that these places reflect the visibility of property from a road by other people (i.e., opportunity), as well as from the place where the farmer lives (i.e., guardianship).

In a later publication, Barclay and Donnermeyer (2011) note that improvements in roads, the increasing cost of farm machinery and farm inputs, increasing reliance on transient or seasonal workers, and encroachment of urbanization into formerly rural and remote areas, have increased the visibility, attractiveness, and accessibility of farm properties. In a study conducted by Omiti et al (2007) in Kenya, farm theft was found to be associated with high market integration and market availability. From the point of view of routine activity theory, this represents an increase in attractiveness of the target. Accordingly, residing near major transportation routes would also increase a farmer's vulnerability to crime because potential offenders can easily traverse the distance between urban and rural areas.

\section{Methodology}

Data for this study came from an exploratory survey of farming households and key informants from the Soy Division in Uasin Gishu County, Republic of Kenya (see figure 1 below). The county is one of the high agricultural potential districts in Kenya and is rightly referred to as part of the grain basket of the country. It produces wheat and maize in large quantities. This survey is part of a wider study carried out in Uasin Gishu County in 2012 which involved 200 primary respondents and 20 key informants. A multistage sampling approach was used to select respondents who were farming households in the Soy division. The sample was drawn from four purposively selected locations (Kibulgeny, Kiplombe, Ziwa and Kipsomba), with respondents living in two villages which were randomly sampled from each location. A total of 25 participants were selected from each village. A list of all farming households was drawn from names given by village elders from the 8 villages. Purposive sampling was used to contact 20 key informants who included chiefs, sub-chiefs, and village elders at the sampled locations.

We sought permission to conduct research from National Institute of Science and Technology of Kenya, the Uasin Gishu County Commissioner, and the County Agricultural Officer. Before the actual collection of data from all participants in the study, each participant was informed on the purpose of the research and their rights concerning the voluntary nature of participation, their right to refuse to answer or stop from answering questions at any time, and assurance of confidentiality of their responses.

Data was collected using a semi structured questionnaire and key informant interviews which was administered by the researchers after seeking verbal consent from respondents. The questionnaire was design with the help of farmers who gave suggestions on the clarity and content of the questions during a field test. The instruments asked farmers about agricultural crime victimisation during the last five years prior to the study. Farmers were 
Factors Influencing Farm Crime in Kenya: Opinions and Experiences of Farmers:

Bunei, Rono \& Chessa

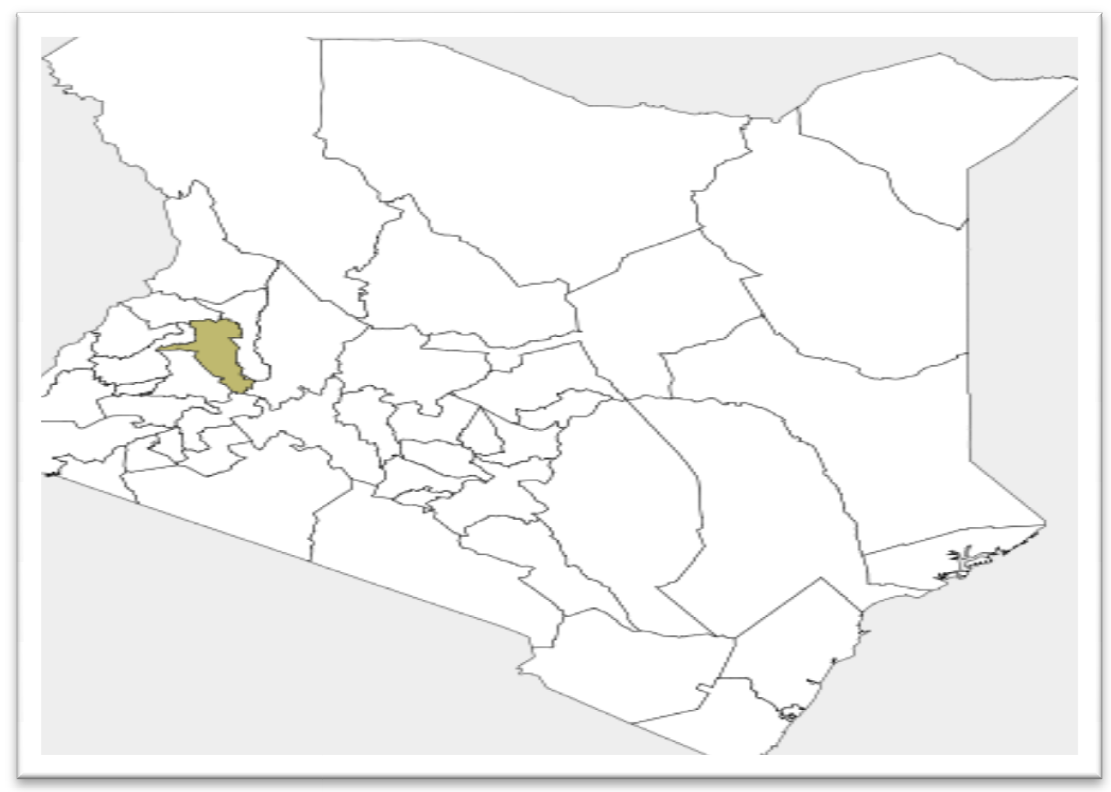

Figure 1: The Study Site of Uasin Gishu County, Kenya

asked to give information on type of agricultural production, characteristics of their operations, and victimization experiences. The focus of the study was those crimes occurring to agricultural operations either directly or indirectly affecting various farming activities. The study concentrated on seven major types of property crime on farms, which included livestock theft, theft of farm machinery, tools, spare parts (including vehicle or machinery parts), theft of farm produce with special reference to grain, theft of agrichemicals (pesticides, herbicides and inputs), theft of farm tools and implements, fuel theft, and vandalism. Questionnaires were administered at a place convenient to the farmer (e.g., resident, farm, or recreational areas).

The unit of analysis for this study was the farmer. Due to the binary character of the dependent variables (victim vs. not a victim for various property offenses), we used logistic regression analysis (Hosmer \& Lemeshow, 2000). The dependent variables for this study were whether the victim had experienced the theft of livestock, fuel, grain, agrichemicals, tools and small equipment, machinery, or the vandalism of farm property. Each dependent variable was coded $1=$ No and $2=$ Yes.

\section{Measures}

Social and economic factors were measured by asking farmers, on a scale of 1 to 4 , how they relate agricultural victimization with certain social-economic factors. The responses included: $1=$ Never; $2=$ Not so often; $3=$ Often; and $4=$ Most often. In total, there were 11 social and economic factors, as shown in Table 2 below. Also, in Table 2, responses for "often" and "most often" were combined so that perceptions of farmers about the causes of crime could be more readily ascertained. In order to account for social decline, farmer 
perceptions of youth unemployment, poverty, youth who do not stay in school, presence of workers with alcohol problems, family members (kin) with alcohol problems, family instability, and farm management by outsiders were included; while increases in the cost of farm inputs, increases in the price of food, low wages for agricultural workers, and farm income represented economic factors.

For the logistic regression analysis, four measures of guardianship based on ecological considerations were developed. The first was a proxy measure of the four sample locations ( 1 = Kibulgeny, $2=$ Kiplombe, $3=$ Kipsomba and 4 = Ziwa). The other three were associated with characteristics of the farm operation, including its size, number of employees, and the number of dependents in the farm family (as an indicator of family size).

Although not included in the logistic regression analysis, we also asked farmers their perceptions of people who commit offenses against farm operations. Specifically, we queried about the gender, age, and educational level of possible perpetrators. We also inquired farmers' opinion as to whether or not those who steal or vandalize farm property were seasonal workers, had a high number of dependents, did not belong to a religious faith, and were members of other ethnic groups.

\section{Results}

\section{Farm Crime Victimization}

Over the five year period to which the respondents were asked to answer, the vast majority of farmers $(85 \%)$ have been victims of tool and small equipment theft, and 81 percent had experienced grain theft (see Table 1, below). The least reported theft was of fuel (23\%) and the theft of machinery (15\%). Of the 200 farmers who participated in the study, 99 percent (198) reported experiencing at least one incident of farm theft or vandalism over the five year period.

Farmers' Perception of Demographic Factors: The majority of farmers believed that theft and vandalism to their farm property was more associated with males (58\%), younger people (53\%), people with low levels of education (60\%), and seasonal workers (56\%). Less than a majority indicated that employees with a high number of dependents (45\%), people who did not belong to a religious group (39\%), and members of ethnic groups other than those of respondents' ethnicity $(28 \%)$ were to be blame for farm thefts.

Table 2 shows the perceptions of respondents about factors associated with farm crime. Gender plays a critical role in explaining crime, according to 58 percent of the respondents. Historically, respondents believe, men are much more likely to steal farm property, especially if they have many family dependents who rely on them to provide food. One farmer remarked that "Women rarely steal, and if they steal, it is because of hunger." 
Factors Influencing Farm Crime in Kenya: Opinions and Experiences of Farmers:

Bunei, Rono \& Chessa

Table 1: Victimization of Farms $(n=200)$

\begin{tabular}{ll}
\hline Type of Offenses & Yes \\
\hline Livestock theft & $(\boldsymbol{\%})$ \\
Fuel theft & 45 \\
Grain theft & 23 \\
Tools and small equipment theft & 81 \\
Agricultural chemical theft & 85 \\
Machinery theft & 48 \\
Vandalism theft & 15 \\
Other types of theft (Green maize, timber & 47 \\
$\quad$ fencing post and beans) & 9 \\
\hline
\end{tabular}

Farmer perceptions of young people (53\%) as the perpetrators, plus those with low education (60\%), fit an image of offenders as people who resort to illegal activities as a type of lifestyle. In particular, young people steal, it is believed, to support a lifestyle influenced by Western images of fashions as seen in the media. As one respondent remarked:

"Currently, youths are preoccupied with new fashions and majority of them are not working. They take alcohol, wear new flashy and fashion clothes and like watching movies and football matches. My son has severally stolen my property to keep up with the demands of modern lifestyles."

A majority of respondents (56\%) believed that seasonal workers, unlike permanent employees, do not have an attachment or commitment to the farm operation. Further, nearly half of the respondents linked farm thefts to employees with a high number of dependents. Thus, the pressure to provide for dependents and the low farm wages predisposes some farm workers to steal. As well, nearly 2 out of 5 respondents thought that people who do not belong to a religion were more likely to steal, believing that people who are members of a religion have higher morals, a better work ethic, and fewer problems with alcohol. Less than one-third of respondents believed that farm workers from other parts of the country who were not members of their own ethnic groups to be people more likely to steal or vandalize farm property. Altogether, the perceptions by farmers about those who steal or destroy farm property are similar to what was found in other research, which tends to blame outsiders and those with little perceived attachment to the local area as the cause for farm crime (Barclay, 2001). 
Table 2: Perceived Demographic, Economic and Social Factors Associated with Property Crime on Farms

\begin{tabular}{|c|c|c|c|}
\hline Factors & $\begin{array}{c}\text { Never } \\
(\%)\end{array}$ & $\begin{array}{c}\text { Not So } \\
\text { Often } \\
(\%)\end{array}$ & $\begin{array}{c}\text { Often or } \\
\text { Most Often } \\
(\%)\end{array}$ \\
\hline \multicolumn{4}{|l|}{ Demographic factors } \\
\hline Male workers & 19 & 23 & 58 \\
\hline Younger workers & 19 & 28 & 53 \\
\hline Low levels of education & 12 & 27 & 60 \\
\hline Seasonal workers & 22 & 21 & 56 \\
\hline Employees high dependency ratio & 28 & 27 & 45 \\
\hline Non believers in a religious faith & 31 & 30 & 39 \\
\hline Other ethnic communities & 37 & 35 & 28 \\
\hline \multicolumn{4}{|l|}{ Economic Factors } \\
\hline Increased cost of farm inputs & 18 & 14 & 68 \\
\hline Low pay among workers & 15 & 23 & 62 \\
\hline Delay of payments to workers & 20 & 23 & 57 \\
\hline Financial difficulties among workers & 13 & 13 & 74 \\
\hline Cost of living other than food & 13 & 22 & 65 \\
\hline Increase in food prices & 11 & 15 & 60 \\
\hline Income or profit of the farm & 43 & 33 & 25 \\
\hline \multicolumn{4}{|l|}{ Social factors } \\
\hline Youth unemployment & 7 & 12 & 81 \\
\hline Poverty and despair & 12 & 12 & 75 \\
\hline Increase in school dropouts & 9 & 21 & 70 \\
\hline Workers with alcohol problems & 13 & 25 & 62 \\
\hline Alcoholism among family members & 23 & 25 & 52 \\
\hline Conflicts in the family & 29 & 25 & 45 \\
\hline Family instability & 33 & 29 & 38 \\
\hline Farm management by outsider & 33 & 31 & 36 \\
\hline
\end{tabular}

Total Number of Respondents $=197$

Farmers' Perception of Economic Factors: With regard to economic factors, it was found that most farmers attributed increasing thefts to increases in cost of farm inputs (68\%), lower pay among farm workers (62\%), delayed payments to workers (57\%), financial difficulties among workers (74\%), the general cost of living (65\%), and increased food prices $(60 \%)$. However, only a small percentage $(25 \%)$ of the respondents believed their own income and profits affected theft and vandalism.

The study found that many respondents believed increases in the costs of farm inputs increased farm thefts. Farm inputs included fertilizers for planting and top dressing, seeds, and fuel. Some farmers were particularly concerned with the high cost of fertilizers. A bag of 


\section{Factors Influencing Farm Crime in Kenya: Opinions and Experiences of Farmers: \\ Bunei, Rono \& Chessa}

fertilizer at the time of the study was valued at Kshs 4,000, which is equivalent to $\$ 45$ (U.S.), and depending on the demand and the value of stolen items, offenders can easily dispose of agrichemicals within a short period of time. Similarly, herbicides and pesticides are expensive. Farmers reported losing these chemicals to farm workers who easily steal and sell them at cheaper prices to other farmers. One farmer noted that:

"It was during planting season when I lost a bag of fertilizer in an amusing way. Fertilizer was so expensive costing about Kshs 4,000²; that stealing a small amount will earn a larger sum of money. My employees quickly poured fertilizer from the planter and hide them in ant bear hole in my shama. ${ }^{3}$. It was only after I accidentally stumble on a small amount of fertilizer scattered that I become curious. I found out later that, it was at this point they stopped, poured and hide fertilizer in a nearby ant bear hole. When I check around, I saw a piece of fertilizer bag protruding from the hole. I check and found it was fertilizer."

Another farmer described these thefts as:

“...I am telling you that, these people (offenders) can steal chemicals in a funny way. If you are not vigilant during the application of chemicals, they can strike you hard. Just imagine, one day, I lost chemicals for spraying rust in a wheat plantation. The perpetrator poured the chemical in small polythene bags that costs Kshs. 2 and carefully tied the polythene so that it cannot mix with water. He dropped the chemical in the sprayer as a way of hiding it. Since my land was so long approximately one kilometre in length, he had planned to drop the chemical on the far end where I could not see. This chemical would cost me Kshs. 2,000. Were it not for a neighbour, he would have succeeded."

In the opinion of respondents, low worker pay and the delayed payments to workers increases farm thefts by tempting employees to steal from their employees in order to offset their debts. Farm workers may feel cheated and exploited after working hard to increase profits, wealth, and prosperity of their employers. These workers may seek revenge through thefts.

It is believed that increases in basic needs and especially food prices increases farm thefts, especially the theft of grain and specifically that of green maize. Theft as a result of hunger in traditional African society was somewhat tolerated, but less so today. Some people still practice this tradition, which is more likely to bring them into conflict with the law. The study further observed that thefts from a farm usually increase when food prices increase. Thefts increase more before crops are ready to be sold on the market and when workers have completely depleted their own food stocks between April and September of each year. Others also steal during harvest periods, especially in December and January every year, when 
workers are able to sell stolen items quickly or when building future food stocks for themselves.

One village elder remarked:

“...I handled a case in which a father of seven children was found having stolen two full bags of green maize in the month of September. When asked why he was stealing; he said he was hungry but the maize cobs were too many. In real sense, he was going to sell."

This quote clearly shows how perpetrators have taken advantage of the leeway the community sometimes affords to those who are caught stealing in the name of hunger. The study observed that when a majority of farm workers become too "broke financially," it becomes more risky for employers. Employees who are constantly short of money may seek opportunities to generate money and resources illegally from employers. The urge to have money predisposes individuals to convert whatever property is at hand to cash. Most farmers do not employ guards and depend on mutual trust with employees, and those who are financially stressed often take advantage to commit crimes.

Unlike other economic factors, increases in farm profits were not perceived to increase farm thefts. Most farms do not have long time employees, since most workers are hired only when farm work activities increase, especially during ploughing, planting, and harvesting seasons. It is believed that prospective offenders usually do not have time to study the financial situations of farmers and hence they may not be bothered by whether farmers for whom they work make a profit or not. Respondents believed that what matters to thieves is how accessible and attractive (available market) items may be for them to steal at opportune times.

Farmers' Perception of Social Factors: Respondents were asked to indicate the extent to which various social factors were thought to be associated with farm crimes. Responses were ranked as follows: youth unemployment (81\%), poverty $(75 \%)$; dropping out of school (70\%), alcoholic workers (62\%) and family members (52\%). Other factors not mentioned by a majority as "often / most often" included conflicts in the family (45\%), family instability $(38 \%)$ and farm management by a non-relative $(36 \%)$. This information was corroborated by a majority of key informants who attributed farm thefts to increasing youth unemployment $(68 \%)$ and poverty $(53 \%)$.

Rural areas are also going through rapid changes which make farms more vulnerable to theft. Diminishing job opportunities and a high number of school dropouts have left many people without work and the skills necessary to acquire work. School dropouts may eventually obtain employment, permanent or temporary, but the wages they received are too low to meet the cost of living, even in rural areas where living expenses are lower than in the city. Indeed, most farmers blamed youth unemployment for thefts on farms. Aspirations and 


\section{Factors Influencing Farm Crime in Kenya: Opinions and Experiences of Farmers: \\ Bunei, Rono \& Chessa}

needs of younger people are changing and younger people find themselves left with limited options for making money legitimately, and therefore become more likely to be involved in antisocial behaviours, such as drug and alcohol use and abuse, and all forms of deviant behaviour, including crime. Farm crime was also associated with poverty levels in an area. It is believed that farmers struggle economically and there is a concomitant increase in farm workers who have a difficult time making ends meet. As the cost of living increases, especially for food and other basics like shelter, clothing, health and education, crime also increases. Poor families and families with many dependents are sometimes compelled by circumstances to cheat or even steal to obtain basic necessities, and the stress of poverty can lead to alcohol abuse, according to many respondents in this study.

One farmer observed:

“...it was unbelievable, for a chang'aa brewer to have held my spanner costing Kshs 1500 as collateral for alcohol debt of Kshs 250 owed by my employee."

From the above scenario, alcoholism tends to compel addicts to do everything possible to get a drink. Alcoholic employees, family members, or even relatives often exchange valuable farm items and farm produce for alcohol. Thus, farmers lose items such as vehicle spares, chemicals, grain, tools, and so on for food or alcohol. One farmer reported:

"I had lost one sack of maize and on my close investigation, my younger daughter told me she had seen Isaac (my brother) taking a sack of maize to a chang'aa brewing den. When I interrogated the brewer, she vehemently said that it was for clearing an accumulated alcohol debt of Kshs 700".

To a lesser extent that other social factors, family instability, and conflicts were perceived to increase farm thefts. Respondents believed that conflicts among relatives and family separations reduce farm vigilance and security on farms.

\section{Ecological Factors}

Farm Crime Victimisation by Location in Uasin Gishu County: In order to examine the impact of ecological factors on farm thefts, property crime types were compared across the four regions in the Usain Ghishu County. As shown in Figure 2, some types of farm crime were more frequent in certain locations, indicating that ecological characteristics there influence crime's occurrence. Across all locations, Kiplombe had the highest incidence of livestock theft (30\%), followed closely by Kibulgeny (29\%), then Ziwa (23\%), and lastly Kipsomba (23\%), based on reports from farmers.

The distribution of reported theft across the four locations for the theft of grain and agrichemicals, and for vandalism as well, suggests that ecological factors were relatively 
unimportant for these property crime types. However, there were large variations for livestock theft, fuel theft, machinery theft, and the theft of machinery parts.

First, the higher incidence of reported livestock theft was in the first two locations, Kiplombe and Kibulgeny, and can be attributed to their nearness to a town and high population density. This suggests that the motivation to steal stock is accessibility to farm property and the availability of a market. Specifically, livestock theft can be linked to the availability of slaughter houses in Eldoret, which is a town close by. Fast sales to slaughterhouses also makes it more difficult to trace lost or stolen stock. Second, the reported theft of machinery and its parts is also higher in locations near the town of Eldoret, namely, Kibulgeny and Kiplombe. Both experienced the highest number of thefts of farm machinery, while Kipsomba, which is the farthest away from a town, had the least amount of reported theft. One-third of farmers in Kibulgeny, which is situated in part of Eldoret, said they had experienced a theft of this type. Thirty percent of farmers in Kiplombe, which borders Eldoret, reported the theft of machinery. Farmers in Ziwa (27\%) and Kipsomba (10\%), which are farthest from a town, were less likely to indicate they had been the victims of machinery theft. Similar to livestock theft, these findings suggest that the theft of such machinery and spare parts is likely influenced by a ready market within a nearby town. Finally, reported fuel theft was highest in Kiplombe and Kipsomba. The higher incidence of fuel theft in Kiplombe and Kipsomba can be linked to the major highways within those locations when compared to Kibulgeny and Ziwa.

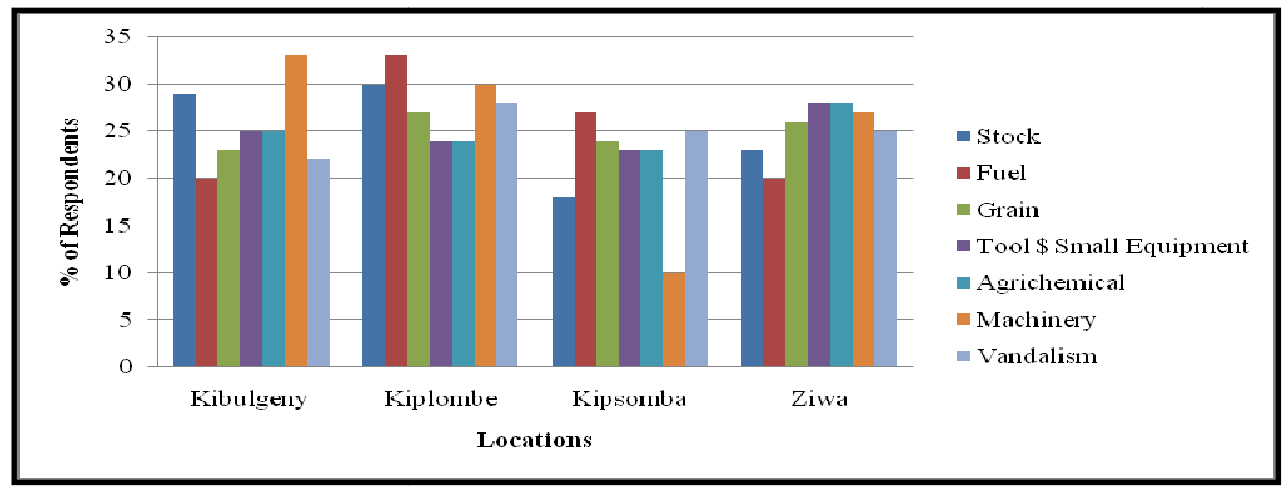

Figure 2: Percent Distribution of Types of Farm Theft by Location

Incidence of Theft across Location: Ecological factors were also measured by incidence of theft across locations (Figure 3). The findings indicate that the majority of farmers residing near the town of Eldoret had the greatest number of theft incidents, while those farther away recorded the least number of incidents. Respondents in Kibulgeny had the highest incidence, with 37 percent from this location recording at least five incidents of property theft, and farmers from Kiplombe recorded the largest proportion of four incidents (26\%). Three incidents were reported by about one-fourth of Ziwa farmers, and 23 percent of 


\section{Factors Influencing Farm Crime in Kenya: Opinions and Experiences of Farmers:}

Bunei, Rono \& Chessa

Kipsomba farmers indicated two incidents of theft. On average, the majority of respondents reported being the victims of three or more crime in all four locations, with the higher rates in Kibulgeny and Kiplombe. In other words, farmers residing near a town were more prone to theft than those who were located farther away. These results agree with the ecology of crime as reported by Barclay (2001) in her review of agricultural crime studies in Australia, Great Britain, and the United States.

Time of Occurrence of Farm theft Types: The results in Figure 4 show that a majority of farm thefts occurred at night. This was particularly true for livestock theft $(88 \%)$, but also for the theft of grain (62\%) and machinery (53\%). The theft of fuel (56\%), tools and small equipment (53\%), and vandalism (51\%), however, more likely occurred anytime. Only the theft of agrichemicals (40\%) occurred with any frequency during the day. Ecologically,

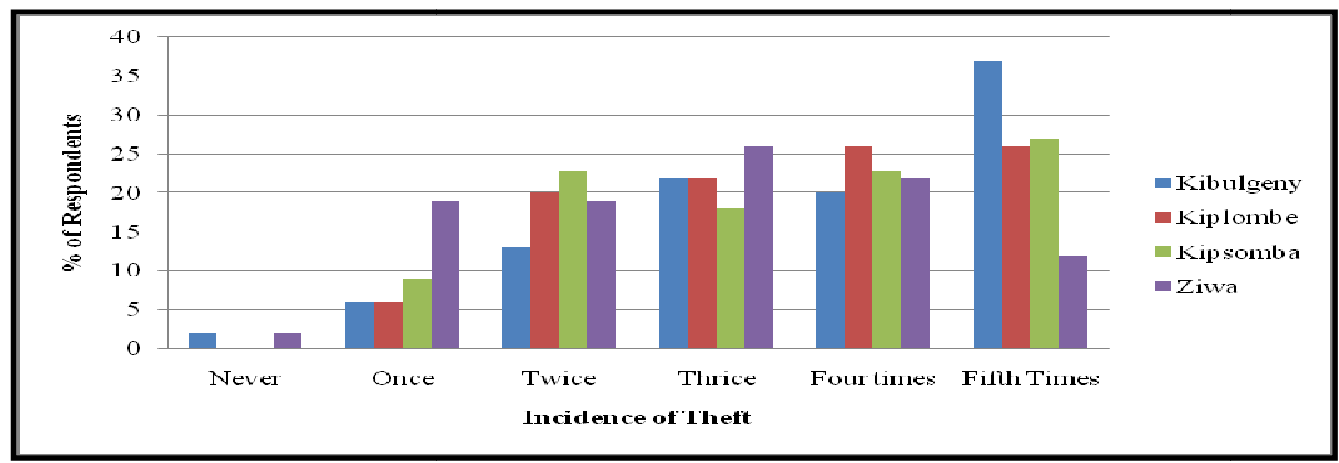

\section{Figure 3: Percentage Distribution of the Number of Theft Incidents by Location}

the time of occurrence of property crime on farms depends on availability, guardianship, exposure, and the portability of the property. Darkness contributes to crime because guardianship measures are reduced and there is greater anonymity, which affords greater opportunity for theft and vandalism. Livestock theft was particularly committed at night when the owners were asleep and there was a low chance of being noticed. Hence, those thefts were more likely to occur during the night were mostly heavy objects and objects of high value, while those which occurred during the day or anytime were mostly associated with lack of guardianship. In particular, agrichemicals are mostly available during the day for use by the farmers or farm workers, and more likely to be safely stored at night.

Incidences of Farm Thefts across Land Sizes: From this study, it is evident that the larger the size of a farm operation, the higher the incidences of reported thefts and vandalism (Figure 5). All farmers with land size of over 200 acres (100\%) had been victimized by at least five different types of farm theft, and a majority of those with $101-200$ (74\%) acres reported experiencing at least four different types of farm crime. In contrast, those owning less than 10 acres had experienced one, two, three and more incidents of theft or vandalism to 
International Journal of Rural Criminology, Volume 2, Issue 1 (December), 2013

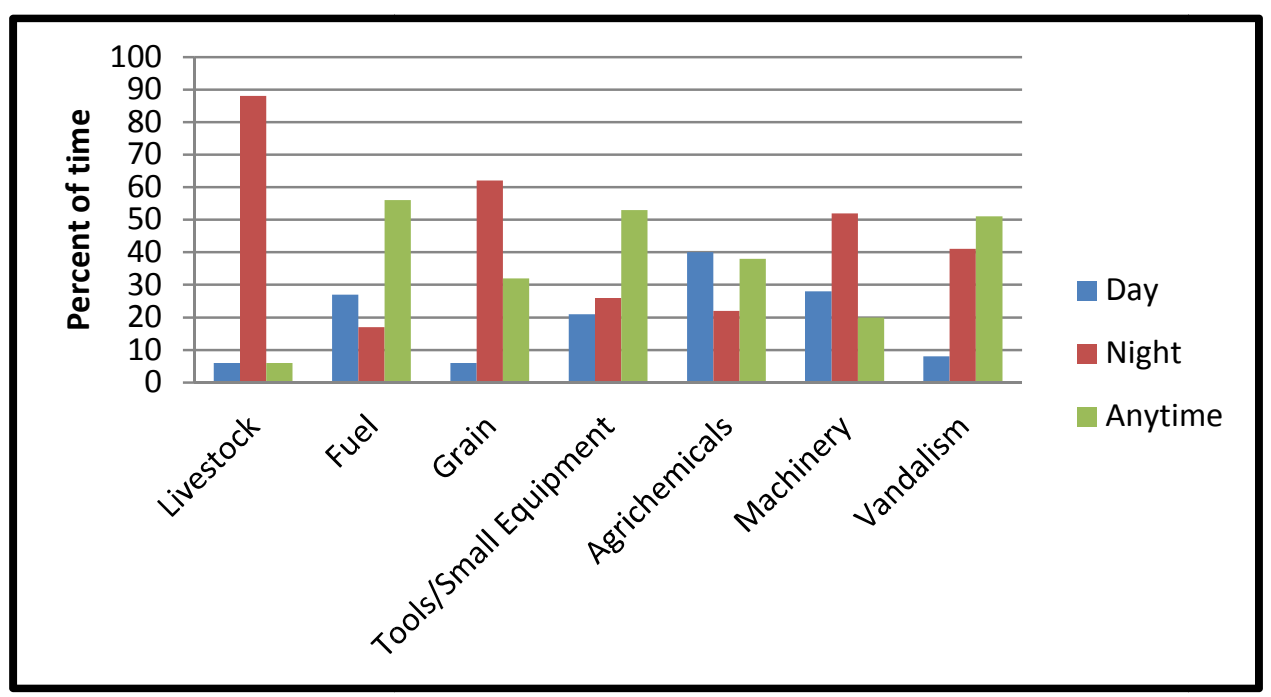

Figure 4: Percentage of Time of Occurrence of Farm Thefts and Vandalism

about the same percentage. The general conclusion is that larger farms were more likely to experience many incidents of theft or vandalism, whilst a larger share of smaller agricultural operations experienced fewer incidents of crime.

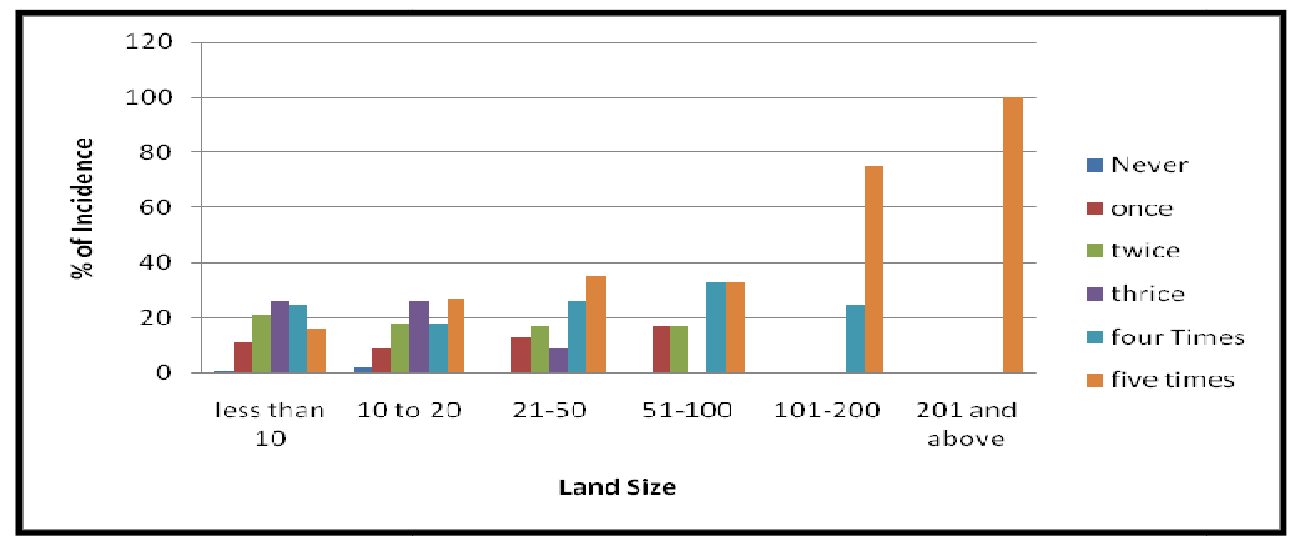

Figure 5: Percent of Crime Incidents by Land Size

\section{Perceived Sources of Motivations and Guardianship Factors Associated with Farm Crime}

It was argued that areas affected by various social and economic factors will generate motivated offenders, in accordance with routine activity theory. A strong association should be found between poor social and economic factors of farming areas and high rates of agricultural crime victimization. In order to account for social conditions, a series of factors were selected, based on the perceptions of the respondents, including youth unemployment, poverty, alcoholism among worker, family instability, presence of school dropouts, and alcoholism among family members. Economic factors included the cost of farm inputs, food 


\section{Factors Influencing Farm Crime in Kenya: Opinions and Experiences of Farmers: \\ Bunei, Rono \& Chessa}

prices, low wages, and high farm income. It was argued that areas affected by these social and economic factors will motivate offenders to commit crime and hence it was used to test the role of motivated offenders in routine activity theory. These results are shown in Table 3.

Family instability was significantly related to reports of grain theft $(b=0.716$, p-value $<0.001)$, dropping out of school $(b=0.657$, p-value $<0.001)$ was associated with the occurrence of fuel theft, and alcoholism among workers $(b=0.661$, p-value $<0.001)$ was tied to the theft of tools and small equipment. Increases in the cost of food prices predicted an effect ( $b=0.538$, p-value $<0.05$ ) on agrichemical theft, while an increase in the farm income produced a negative (impact $b=-0.468, p$-value $<0.05$ ) relationship on the occurrence of theft of tools and small equipment.

Kenya, like other African countries, is undergoing rapid transformations in its social structures, such as a weakening of clanism and kinship / extended family networks. These networks are weakening, leading to less guardianship measures from close members of formerly tight-knit rural communities (Omit et al, 2007). As a result, the immediate family members, neighbours or even friends can become the prime offenders for property crime on farms (Daily Nation, 2011b).

Accordingly, a positive coefficient of family instability showed that a family that is not united and prone to conflicts, quarrels, and disputes can generate individuals from both within the family and outside who are motivated to commit crimes, as well diminishing guardianship over farm property, hence, making farms more vulnerable to crime. Members of the family who feel sidelined may either steal farm properties or reduce their guardianship measures by collaborating with prospective offenders. Areas that are characterised by higher rates of school dropout generate individuals who are not skilled and are more likely to steal farm properties, especially fuel, because it is expensive and readily sold, providing monies to purchase basic needs or to live a more cosmopolitan lifestyle. Use of alcohol, especially among workers, produces motivations to steal farm properties to get money to buy basic commodities and items that meet their pleasures. As a result, farm items, especially tools and small equipment, may be quickly turned into cash by farm employees so they can buy alcohol.

Further, inflation in food prices disposes an individual to commit crime by stealing farm chemicals, which are of high value. An increase of farm income heightens the motivations to steal farm tools and equipment because as farm income increase, more tools and equipment are used in the operation itself, making it more difficult for the farmer to keep track of everything, hence, reducing the farmer's ability to keep surveillance over valuable items. 
International Journal of Rural Criminology, Volume 2, Issue 1 (December), 2013

As well, results from this analysis shows that, vandalism, theft of livestock and machinery theft had no significant statistical relationship with any of the social and economic factors, as perceived by farmers interviewed for this study. This suggests that the motivation

\section{Table 3: Logistic Regressions Analysis of Agricultural Crime Types by Factors Indicating Both Sources of Motivation and Guardianship}

\begin{tabular}{|c|c|c|c|c|c|c|c|}
\hline \multicolumn{8}{|c|}{ Dependent Variables } \\
\hline \multirow[b]{2}{*}{$\begin{array}{l}\text { Independent } \\
\text { Variables }\end{array}$} & \multirow{2}{*}{$\begin{array}{l}\text { Livestock } \\
\text { Coefficients }\end{array}$} & \multirow{2}{*}{$\begin{array}{c}\text { Fuel } \\
\\
\text { Coefficients }\end{array}$} & \multirow{2}{*}{$\begin{array}{c}\text { Grain } \\
\text { Coefficients }\end{array}$} & \multirow{2}{*}{$\begin{array}{c}\text { Tool \& } \\
\text { Small } \\
\text { Equipment } \\
\text { Coefficients }\end{array}$} & \multirow{2}{*}{$\begin{array}{c}\text { Agrichemicals } \\
\text { Coefficients }\end{array}$} & \multirow{2}{*}{$\begin{array}{l}\text { Machinery } \\
\text { Coefficients }\end{array}$} & \multirow{2}{*}{$\begin{array}{l}\text { Vandalism } \\
\text { Coefficients }\end{array}$} \\
\hline & & & & & & & \\
\hline Constant & -0.708 & -5.028 & -3.851 & 0.207 & -2.989 & -2.812 & -1.624 \\
\hline \multicolumn{8}{|c|}{ Sources of Motivations } \\
\hline $\begin{array}{l}\text { Youth Unem- } \\
\text { ployment }\end{array}$ & -0.06 & -0.432 & 0.199 & -0.068 & -0.436 & -0.063 & -0.149 \\
\hline Poverty & -0.052 & -0.205 & 0.134 & -0.057 & -0.096 & 0.139 & 0.099 \\
\hline $\begin{array}{l}\text { Alcoholic } \\
\text { Worker }\end{array}$ & 0.153 & 0.379 & 0.140 & $0.661^{*}$ & $0.411^{* *}$ & 0.113 & 0.027 \\
\hline $\begin{array}{l}\text { Family } \\
\text { Instability }\end{array}$ & 0.121 & -0.273 & $0.716^{* *}$ & -0.304 & 0.028 & -0.112 & 0.13 \\
\hline $\begin{array}{l}\text { School } \\
\text { Dropout }\end{array}$ & -0.202 & $0.657^{*}$ & 0.039 & 0.371 & 0.145 & -0.012 & 0.051 \\
\hline Alcoholic kin & 0.044 & 0.167 & -0.342 & -0.237 & -0.097 & 0.348 & 0.12 \\
\hline $\begin{array}{l}\text { Cost of Farm } \\
\text { Inputs }\end{array}$ & 0.069 & -0.239 & 0.037 & 0.325 & -0.015 & -0.209 & 0.075 \\
\hline $\begin{array}{l}\text { Cost of Food } \\
\text { Prices }\end{array}$ & 0.319 & 0.425 & 0.195 & -0.112 & $0.538^{*}$ & 0.190 & 0.242 \\
\hline Low wages & 0.003 & -0.239 & -0.315 & 0.058 & -0.072 & -0.316 & -0.197 \\
\hline $\begin{array}{l}\text { High Farm } \\
\text { Income }\end{array}$ & -0.100 & 0.116 & 0.004 & $-0.468 * *$ & 0.121 & 0.09 & -0.115 \\
\hline \multicolumn{8}{|c|}{ Guardianship Measures } \\
\hline Location & $-0.332 *$ & -0.056 & -0.193 & -0.118 & 0.043 & -0.207 & -0.094 \\
\hline Land size & -0.146 & $0.425^{* *}$ & $0.501 * *$ & -0.131 & $0.303 * *$ & -0.004 & $0.338^{* *}$ \\
\hline $\begin{array}{l}\text { Number of } \\
\text { Employees }\end{array}$ & 0.286 & $0.732 * *$ & 2.182 & 0.741 & $0.545 * *$ & $0.539 * *$ & 0.111 \\
\hline $\begin{array}{l}\text { Number of } \\
\text { Dependants }\end{array}$ & 0.112 & 0.256 & 0.212 & -0.120 & 0.058 & 0.079 & 0.047 \\
\hline R Square & 0.110 & 0.343 & 0.257 & 0.187 & 0.213 & 0.137 & 0.112 \\
\hline
\end{tabular}

Note: $N=197 . * * p<.05, * p<.001$

to commit these crimes are not generated from within the community. One possible interpretation is that livestock and machinery are easily identifiable as compared to grain, agrichemicals, fuels, tools, and equipment. This characteristic limits the motivation to target this specific kind of property. 


\section{Factors Influencing Farm Crime in Kenya: Opinions and Experiences of Farmers: \\ Bunei, Rono \& Chessa}

Unlike other types of farm crime, vandalism does not yield any benefits from the offender and hence minimizes the motivation. In agreement with this supposition, none of the associations between farm crime and the various motivational and guardianship factors were statistically significant, with the exception of land size. Land size was positively associated with the reported occurrence of vandalism.

\section{Guardianship and Farm Crime}

In order to test the relationship of guardianship characteristics of the farming operation and property crime, the logistic regression also included four measures of a farm's ecology, namely, location of the farm, land size, number of employees, and number of dependants across the seven types of farm theft. It was hypothesized that there is a clear association between certain guardianship factors and experiences with agricultural crime.

The logistic regression model revealed a statistical relationship between livestock victimisation and the location of the farm. A negative coefficient $(b=-0.332, p$-value $<0.05)$, shows that areas near urban centres experienced the most victimisation of this type. This can be attributed to availability of a ready market in urban centres. In other words, the farther a rural area is from a town, the lower the level of livestock theft.

The size of the land was significantly related to thefts of fuel $(b=0.425, p$-value $<0.05)$, grains $(b=0.501, p$-value $<0.05)$, agrichemicals $(b=0.303, p$-value $<0.05)$ and vandalism $(b=0.338, p$-value $<0.05)$. Large farms were likely to be victimized because guarding all farm property is more difficult, hence, creating more opportunities for the commission of crime when other factors create a greater motivation on the part of possible offenders.

The study also found out that a higher number of employees was statistically significant with the occurrence of thefts of fuel $(b=0.732$, $p$-value $<0.05)$, agrichemicals $(b=0.545, p$ value $<0.05)$, and machinery theft $(b=0.539$, $p$-value $<0.05)$. The study revealed that thefts of machinery, agrichemicals and fuel appear to be linked to employees and can be construed in routine activity theory as theft associated with the presence of motivated offenders. Related to this is the presence of many seasonal farm workers. During critical farming times, such as planting, weeding, and harvesting, it is common for farmers to hire a large number of seasonal employees who may not have grown up in a rural community. These workers may travel from urban areas to work on farms for daily wages and later go back to their homes in a town. It is during these times that they may spot farm items and produce that can easily be stolen, if the opportunity arises.

The number of dependents in a farm family had no significant direct impact on the levels of agricultural crime. This shows that as the number of dependents increases, guardianship does not increases, which is contrary to the principles behind routine activity theory. Also, the theft of tools and small equipment and vandalism was not significantly 
related to any guardianship variable tested in this study, signifying that these types of farm crime were not determined by the ability of farm owners to keep watch over their property. Over-all, the prediction that there will be an association between guardianship of farm property and agricultural crime victimization can be only partially accepted.

\section{Summary and Conclusions}

The study has shown that farm crime is linked to the perceived social and economic changes affecting rural Kenya, including increases in school dropouts, youth unemployment, alcoholism, family instability, and increasing food prices in rural areas. Inflation in food prices have been associated with increases in agrichemical theft while higher rates of school dropouts increases fuel theft. Family instability is linked to an increase in grain theft whereas alcoholism among workers was associated with the theft of farm tools and small equipment. The study discovered that vandalism and theft of livestock and machinery was not associated with any of the social conditions of the neighbourhoods indicating that offenders of these crimes may not be members from the same community.

These ongoing social and economic transformations, in the opinion of respondents, in terms of family instability, high alcoholism, school dropouts, youth unemployment and increases in cost of food prices have served to increase the number of criminal characters and criminal opportunities owing to diminishing methods of social control in rural areas. Opportunistic offenders both from within rural areas and outside are taking advantage of the apparent laxity in guardianship to perpetrate crime. In general, farm crime has occurred as a result of social changes in rural areas combined with the globalization in which far distant ideas impact individual and groups everywhere.

Further, the study findings showed that farm ecology plays a role in explaining the occurrence of agricultural crimes. The major finding on ecological factors is that farming communities that share borders with urban centres $(37 \%)$ reported higher levels of farm crime as compared to isolated rural and remote areas. The study observed locations next to urban centres experienced the highest levels of various crimes, in particular, livestock theft. Further, it was evident that large farms are more victimized than small farms; the higher the land size, the higher the levels of thefts of fuel, agrichemicals and grains. Another important finding from this study was that the more employees working on a farm, the higher the thefts of fuel and machinery. In summary, the study has observed that farm crimes depends on the environmental characteristics of farms in which, large farms are victimized more than smaller farms, and those with more employees experience more farm theft.

\section{Implications on Routine Activity Theory}

This study supports routine activity theory. This theory was used to represent micro level process where individuals make decisions that solve problems, which includes decisions 


\section{Factors Influencing Farm Crime in Kenya: Opinions and Experiences of Farmers: \\ Bunei, Rono \& Chessa}

by members of farm families, farm workers, and others to commit crime, to report crime, or to prevent crimes. It is evident from this study that items that are more attractive, accessible, valuable, transportable, and visible are more likely to be stolen. Further, such crimes occur in a specific area which allows motivated offenders to access the target in the absence of capable guardianship. Livestock theft occurs in areas adjacent to town centres where stock can be transported and disposed of at a slaughterhouse, hence leaving little or no trace of evidence.

Similarly, farm properties like chemicals and fuel are more valuable, visible, and easily accessible due to the difficulty of easily identifying criminals, owing to the heterogeneous population around urban centres where people no longer know all of their neighbours. Further, urbanization, improved communication networks, higher population density, greater competition, more expensive lifestyles, and unemployment have all eroded rural lifestyles where social life was at one time more closely knit and based on cooperation and mutual trust. Moreover, land size is a significant predictor of farm crime, especially theft of fuel, machinery, and vandalism, demonstrating that lack of guardianship measures on large farms creates opportunities for the theft of properties.

In addition, farm areas where there are believed to be high rates of family instability, unemployment, poverty, school dropouts and alcoholism were more likely to have higher incidences of crime rates. Unemployment was a significant predictor of agrichemical theft, dropping out of school was associated with fuel theft, while family instability was a significant predictor of grain theft, and alcoholism was linked to thefts of tools, small equipment and agrichemicals. These conditions generate individuals who are motivated to commit crime, as well decreasing guardianship. The results are the creation of criminogenic opportunities and motivations to commit crime, based on the perceptions of the farmers in our sample.

In conclusion, little is known about crimes against farm operations in Kenya and yet agriculture plays a significant role in the Kenyan economy. It is evident from this study that crime against farms is becoming a problem. Higher value farm property such as livestock, fuel, chemicals, machinery parts (injector pumps, engine starters), equipment, tools and farm

produce are easily turned into cash by thieves. The continued social and economic changes in rural areas are posing a threat to the development of rural areas. More proactive measures should be channelled towards improving the social and economic status of people living in rural areas of Kenya. Further, a concerted partnership-based approach between the government, the community, and farmers is needed to tackle farm crimes at both the community and national level.

\section{Policy Recommendations}


The government of Kenya should develop proactive measures that would address the plight of the youth and the most disadvantaged in the community, including the creation of employment opportunities for youth and the economically vulnerable, improving basic technical skills, provision of affordable middle level education, and adherence to minimum wages limits among farm owners.

Farmers should adopt new management styles in their farms by incorporating practices such as proper rewards of employees who report crime, improved social interaction with employees - such as through just treatment of farm workers and paying wages on-time proper record-keeping, better farm security, and insurance to reduce risk when crimes occur. As well, farmers should be encouraged to form community watch groups or community policing initiatives and forums to discuss security issues. Farmers should be ready to work proactively with their neighbours, community, and police to discuss crime and community safety issues.

\section{Endnotes}

${ }^{1}$ This paper is derived from a Master of Philosophy (Sociology) research undertaken by the first author at Moi University, Kenya. The authors wish to appreciate contributions and information from rural farmers in Soy Division in Uasin Gishu County and other respondents who made the research and this article a success.

${ }^{2}$ At the time of the study, one U.S. dollar was equivalent to Kshs. 85.

${ }^{3}$ Shamba is a Kiswahili word referring to a piece of land that is cultivated and has crops on it.

${ }^{4}$ Chang' aa is a form of local brew made through a process of fermentation and distillation common in Kenya. 
Factors Influencing Farm Crime in Kenya: Opinions and Experiences of Farmers:

Bunei, Rono \& Chessa

\section{References}

Anderson, K. M., \& McCall, M. (2005). Farm crime in Australia. Canberra, AU: Australian Institute of Criminology, retrieved on $7^{\text {th }}$ February, 2011 from: $w w w$.aic.gov.au/publications/current\%20series/cfi/101-120/cfi119.aspx

Andrig, J. C., \& Barasa, T. (2011). Cops and crime in Kenya. Norwegian Institute of International Affairs, Oslo, retrieved on 29th January, 2012 from http://www.isn.ethz.ch/isn/Digital-Library/Publications/Detail

Barclay, E. M. (2001). A review of related literature on agriculturalcrime. Institute for Rural Futures, University of New England, retrieved on $21^{\text {st }}$ November, 2010 from: www.criminologyresearchcouncil.gov.au/reports/barclay.pdf

Barclay, E. M., \& Donnermeyer J.F. (2011). Crime and security on agricultural operations. Security Journal, 24, 1-18.

Barclay, E.M., \& Donnermeyer, J.F. (2002). Property crime and crime prevention on farms in Australia. Crime Prevention and Community Safety: An International Journal. 4, 47-61.

Barclay, E.M, Donnermeyer, J. F., Doyle, B. P., \& Talary, D. (2001). Property crime victimisation and crime prevention on farms. Report to the NSW Attorney General's Crime Prevention Division (Report No. 01.2). Armidale, New South Wales: Institute for Rural Futures, University of New England.

Bouffard A. L., \& Muftíc R.L. (2006). The "rural mystique": Social disorganization and violence beyond urban communities. Western Criminology Review, 7, 56-66.

Bursik, R. J., \& Grasmick. H. G. (1993). Neighbourhoods and crime: The dimensions of effective community control. NY: Lexington Books.

Coast Week. (2012). Rampant theft of green maize hamper harvest in Trans Nzoia. Coastweek Newspapers Ltd: Nairobi: 10. Publish on $5^{\text {th }}$ October, 2012. Available online at http://www.coastweek.com/3540_maize.htm

Cohen, L. E., \& Felson, M. (1979). Social change and crime rates trends: A routine activities approach. American Sociological Review, 44, 588-608

Clarke, R. V., \& Felson, M. (Eds.). (1993). Routine activity and rational choice. New Brunswick, NJ: Transaction. 
International Journal of Rural Criminology, Volume 2, Issue 1 (December), 2013

Daily Nation (2011b). Kenya coffee growers lose millions as thieves raid factories. Nation Media: Nairobi: Publish on $21^{\text {st }}$ March, 2011. Available online at http://www.nation.co.ke/News/Kenya-coffee-growers-lose-millions/-/1056/1291780//uyrpjd/-/index.html

Daily Nation (2011a). Large and small scale farming in Uasin Gishu. Nation Media: Nairobi: 26. Publish on $21^{\text {st }}$ March, 2011.

Donnermeyer, J.F., \& Barclay E. M. (2005). The policing of farm crime. Police Practice and Justice Research, 6, 3-17.

Felson, M. (2002). Crime and everyday life. ( ${ }^{\text {rd }}$ Edition). London: Sage.

Feyen, C. (1989). Battered rural women: An exploratory study of domestic violence in a Wisconsin County. Wisconsin Sociologist, 261, 17 -32.

Hosmer, D., \& Lemeshow, S. (2000). Applied logistic regression. New York, NY: Wiley.

Jones, J. (2008). Farm crime on Anglesey: Local partner's and organisations. Views on the Issue, second report, January 2008. Retrieved on $7^{\text {th }}$ December, 2011 from http://www.aber.ac.uk/en/media/jane-jones---second-report.pdf

Marshall B., \& Shane J. (2005). Crime in rural areas: A review of the literature for the Rural and Evidence Research Centre. London: University College London,

McCall, M. (2003). Results from the 2001-02 National Farm Crime Survey. Australian Institute of Criminology, Trends and Issues in Crime and Criminal Justice, No.266.

Mears, D.P., Scott, M.L., \& Bhati, A.S. (2007a). Opportunity theory and agricultural crime victimization. Rural Sociology, 72, 151-184.

Mears, D.P., Scott, M.L., \& Bhati, A.S. (2007b). Policy, theory and research from an evaluation of an agricultural crime prevention program. Washington, D.C.: The Urban Institute.

Omiti J. (2007). Participatory prioritization of issues in smallholder agricultural commercialization in Kenya. Kenya Institute for Public Policy Research and Analysis Annual Report 2006/07: Nairobi: KIPPRA.

Owuor W., Booker, O, Job, P. C., \& Argwings, G.M. (2010). Role and performance of Ministry of Agriculture in Eldoret West District. Future Agricultures Consortium Secretariat, University of Sussex, Brighton. 
Factors Influencing Farm Crime in Kenya: Opinions and Experiences of Farmers:

Bunei, Rono \& Chessa

Republic of Kenya (2006). Agrarian reforms and rural development: Challenges and options for revitalizing rural communities in Kenya: A national report of Kenya. Paper presented at the International Conference on Agrarian Reforms and Rural Development, Port Alerge, Brazil on March 7, 2006. Retrieved on 18th November, 2011 from http://www.icarrd.org/en/icard_doc_down/national_Kenya.doc.

Republic of Kenya (2008). Well-being in Kenya: A social-economic profile. English Press Limited, Nairobi.

Spore Magazine (2009). Theft: Tactics for battling crime. Publication of the Technical Centre for Agricultural Land Rural Cooperation (CTA), 129, 10-11. Retrieved on $17^{\text {th }}$ March, 2011 from: http://spore.cta.int/images/stories/pdf/SE139-web.pdf

Swanson, C.R. Chamelin, N.C., \& Territo, L. (2000). Criminal investigation. Boston: McGraw Hill.

Syverson, K. (2009). Theft prevention: Tips to reduce your vulnerability to equipment or horse theft. America's Horse Daily. Retrieved on 18th March, 2011 from http://www.americahorsedaily.com

Tonnies, F. (1963). Community and society. New York: Harper Books. 